\title{
Glucose stimulates human beta cell replication in vivo in islets transplanted into NOD-severe combined immunodeficiency (SCID) mice
}

\author{
H. E. Levitt • T. J. Cyphert • J. L. Pascoe • D. A. Hollern • N. Abraham • \\ R. J. Lundell • T. Rosa - L. C. Romano • B. Zou • C. P. O'Donnell • A. F. Stewart • \\ A. Garcia-Ocaña $\cdot$ L. C. Alonso
}

Received: 25 May 2010 /Accepted: 31 August 2010 / Published online: 9 October 2010

(C) Springer-Verlag 2010

\begin{abstract}
Aims/hypothesis We determined whether hyperglycaemia stimulates human beta cell replication in vivo in an islet transplant model

Methods Human islets were transplanted into streptozotocininduced diabetic NOD-severe combined immunodeficiency mice. Blood glucose was measured serially during a 2 week graft revascularisation period. Engrafted mice were then catheterised in the femoral artery and vein, and infused intravenously with BrdU for 4 days to label replicating beta cells. Mice with restored normoglycaemia were co-infused with either $0.9 \%$ (wt $/ \mathrm{vol}$.) saline or $50 \%$ (wt/vol.) glucose to generate glycaemic differences among grafts from the same donors. During infusions, blood glucose was measured daily. After infusion, human beta cell replication and apoptosis were measured in graft sections using immunofluorescence for insulin, and BrdU or TUNEL.

Results Human islet grafts corrected diabetes in the majority of cases. Among grafts from the same donor, human beta cell proliferation doubled in those exposed to higher glucose relative to lower glucose. Across the entire cohort of grafts, higher blood glucose was strongly correlated with increased beta cell replication. Beta cell
\end{abstract}

\footnotetext{
H. E. Levitt - T. J. Cyphert · J. L. Pascoe • D. A. Hollern •

N. Abraham - R. J. Lundell - T. Rosa $\cdot$ A. F. Stewart

A. Garcia-Ocaña $\cdot$ L. C. Alonso $(\bowtie)$

Division of Endocrinology and Metabolism,

University of Pittsburgh School of Medicine,

200 Lothrop St, BST E1140,

Pittsburgh, PA 15261, USA

e-mail: 1ca4@pitt.edu

L. C. Romano $\cdot$ B. Zou • C. P. O’Donnell

Division of Pulmonary, Allergy and Critical Care Medicine,

University of Pittsburgh,

Pittsburgh, PA, USA
}

replication rates were unrelated to circulating human insulin levels or donor age, but tended to correlate with donor BMI. Beta cell TUNEL reactivity was not measurably increased in grafts exposed to elevated blood glucose.

Conclusions/interpretation Glucose is a mitogenic stimulus for transplanted human beta cells in vivo. Investigating the underlying pathways may point to mechanisms capable of expanding human beta cell mass in vivo.

Keywords Glucose $\cdot$ Human islets $\cdot$ Hyperglycaemia . Insulin · Mitosis · NOD-SCID mice · Proliferation · Replication · Transplantation
Abbreviations
ICRC Islet Cell Resource Center
IEQ Islet equivalent
SCID Severe combined immunodeficiency

\section{Introduction}

Expansion of human beta cells through replication is one of the principal goals of current diabetes research. However, techniques to expand human beta cells lag behind those for rodents. Human islets are different from rodent islets with respect to cellular composition, architecture, toxin susceptibility, replication rates and even fundamental properties such as basement membrane structure and means of glucose transport [1-8]. To this end, translating findings described in rodents to human beta cells is non-trivial and important.

We set out to determine whether elevated glucose stimulates human beta cell replication in vivo. This is a fundamental, unanswered question with direct implications for diabetes care, as the answers may identify pathways 
leading to new therapeutics and may also help establish optimal glycaemic control in recipients of islet transplants.

Glucose drives rodent beta cell replication in vitro [912] and in vivo [13-18]. Teleologically, high glucose levels should direct beta cell expansion, thus increasing insulin secretory capacity. In general, replication in adult human beta cells is infrequent [19-22]. Studies exploring whether hyperglycaemia is associated with increased beta cell replication in the endogenous human pancreas are equivocal. In a large autopsy-based study no increase in beta cell replication was seen in diabetic individuals [22]. A patient with new-onset type 1 diabetes, who required pancreatectomy for an unrelated reason, was reported to have increased beta cell replication [20]. However, in individuals newly diagnosed with diabetes who died from ketoacidosis, beta cell replication was not increased [19]. Patients requiring two sequential pancreatectomy surgery procedures had elevated blood glucose at the time of the second procedure, but no increase in beta cell replication [21]. Therefore, studies of human pancreas tissue do not support the hypothesis that hyperglycaemia increases human beta cell replication, although the many variables attendant to human life, disease and death may mask findings.

Nevertheless, in vitro studies do suggest that glucose stimulates human beta cell replication during short-term exposure. High glucose $(33 \mathrm{mmol} / \mathrm{l})$ increased proliferation after 1 to 2 days of culture, but inhibited proliferation and caused cell death after 4 to 10 days of culture [23-25]. Human beta cell replication was higher after 2 days in culture at $5.6 \mathrm{mmol} / \mathrm{l}$ glucose than at $2.8 \mathrm{mmol} / \mathrm{l}$ [26]. Glucose synergised with lithium chloride to activate human beta cell replication ( $8 \mathrm{mmol} / \mathrm{l}$ vs $5 \mathrm{mmol} / \mathrm{l})$ [27]. Thus, cell culture experiments do suggest that glucose may have mitogenic effects on human beta cells.

Transplantation of human islets into immune-compromised mice is a useful technique to study human beta cells in an in vivo environment $[28,29]$. Engrafted human islets exposed for 2 weeks to either severe hyperglycaemia $(24 \mathrm{mmol} / \mathrm{l})$ or normoglycaemia $(4 \mathrm{mmol} / \mathrm{l})$ showed no difference in beta cell replication [26]. On the other hand, human islets transplanted into obese hyperglycaemic $(9.0 \mathrm{mmol} / \mathrm{l}$ vs $6.4 \mathrm{mmol} / \mathrm{l}$ ) ob/ob mice had a doubled rate of beta cell proliferation [30]. To date, no study has effectively isolated glucose as a variable for determining whether hyperglycaemia in a physiologically relevant range alters human beta cell replication in vivo.

We have previously shown that hyperglycaemia induced by intravenous infusion of glucose increases beta cell replication in the mouse pancreas [13]. To explore the impact of glucose on human beta cell replication in vivo, we have now applied the infusion model to mice transplanted with human islets. This experimental set-up delivers significant advances over previous technologies, including:
(1) exposure of engrafted human islets to a controlled physiological range of blood glucose levels, relevant to the normal and prediabetic postprandial state; (2) isolation of glucose as a variable, without confounding effects due to obesity and chronic diabetes; (3) constant delivery of BrdU regardless of glycaemic status; and (4) serial unhandled blood sampling to avoid stress-related variability in glucose measurements. Using this system, we tested whether elevated blood glucose stimulates human beta cell proliferation in vivo.

\section{Methods}

Human islet donor characteristics Islets from 12 nondiabetic human cadaveric donors were obtained from the Islet Cell Resource Center (ICRC; http://icr.coh.org/, accessed 7 September 2010) (Table 1). Donors ranged in age from 27 to 76 years; islets from one 7-year-old donor were initially included in the study, but were subsequently excluded from analyses because of the marked biological differences between juvenile and adult islets [31]. Of the remaining 11 donors, four were female, six male and one unrecorded. BMI ranged from low-normal $\left(19.6 \mathrm{~kg} / \mathrm{m}^{2}\right)$ to severely obese $\left(43.8 \mathrm{~kg} / \mathrm{m}^{2}\right)$. ICRC-determined islet purity was between 70 and $95 \%$, viability was between 80 and $95 \%$.

Human islet transplantation All animal handling was in accordance with approved Institutional Animal Care and Use Committee protocols at the University of Pittsburgh; use of human islets was approved by the University of Pittsburgh Institutional Review Board. Human islets were transplanted under the kidney capsule of 2- to 3-month-old, streptozotocin-induced diabetic male NOD-severe combined immunodeficiency (SCID) mice (Jackson laboratory, Bar Harbor, ME, USA) as previously described [28]. Briefly, NOD-SCID mice were rendered diabetic by intraperitoneal injection of $125 \mathrm{mg} / \mathrm{kg}$ streptozotocin for two consecutive days. Diabetes was determined by the presence of hyperglycaemia $(>16.7 \mathrm{mmol} / \mathrm{l})$, polyuria and weight loss. Random non-fasted blood glucose was measured from tail snip using a portable glucometer. After at least 3 days of hyperglycaemia, mice were transplanted with 2,500 to 4,000 islet equivalents (IEQ) beneath the kidney capsule. IEQ was defined as: $125 \mu \mathrm{m}$ diameter islet $=1$ IEQ. The initial two transplants were 4,000 IEQ, but subsequently the number of IEQ transplanted per donor was reduced until it became clear that 2,500 IEQ were sufficient to reverse hyperglycaemia [28, 29]. Recipients receiving $>2,500$ IEQ were not different from those receiving 2,500 IEQ with respect to blood glucose, plasma insulin, age or BMI. Multiple mice transplanted from the same donor received the same number of IEQ. Blood glucose levels 
Table 1 Donor characteristics

\begin{tabular}{|c|c|c|c|c|c|c|c|c|}
\hline Donor no. & Age (years) & Sex & Race & BMI $\left(\mathrm{kg} / \mathrm{m}^{2}\right)$ & Purity $(\%)^{\mathrm{a}}$ & Viability $(\%)^{\mathrm{a}}$ & Grafts $(n)$ & IEQ \\
\hline 1 & 35 & M & White & 30.0 & 70 & nd & 1 & 4,000 \\
\hline 2 & 46 & nd & White & 24.0 & 70 & 85 & 1 & 4,000 \\
\hline 3 & 28 & $\mathrm{~F}$ & White & 31.8 & 88 & 95 & 1 & 3,500 \\
\hline 4 & 60 & $\mathrm{~F}$ & White & 22.6 & 95 & 85 & 2 & 2,800 \\
\hline 5 & 45 & M & White & 19.6 & 95 & 95 & 3 & 2,500 \\
\hline 6 & 40 & $\mathrm{~F}$ & nd & 33.7 & 90 & 86 & 1 & 2,500 \\
\hline 7 & 27 & M & Hisp & 29.2 & 90 & 95 & 2 & 2,500 \\
\hline 8 & 76 & M & White & 25.8 & 77 & 80 & 3 & 2,500 \\
\hline 9 & 27 & M & AA & 35.2 & 95 & 90 & 3 & 2,500 \\
\hline 10 & 58 & M & Hisp & 31.5 & 95 & nd & 3 & 2,500 \\
\hline 11 & 43 & $\mathrm{~F}$ & White & 43.8 & 80 & 85 & 2 & 2,500 \\
\hline 12 & 7 & $\mathrm{~F}$ & nd & nd & nd & nd & 2 & 2,500 \\
\hline
\end{tabular}

${ }^{\mathrm{a}}$ As reported by the ICRC

AA, African-American origin, F, female; Hisp, Hispanic origin; M, male; nd, not documented

were measured on days $1,3,5,10$ and 14 after transplant, before surgical catheterisation and infusion.

Mouse catheterisation and infusions Detailed protocols on surgical catheterisation, tether system, housing, catheter maintenance, arterial blood sampling, erythrocyte return and techniques for venous infusion can be found in the online supplement of a previous publication [13]. Transplanted mice with free access to food and water were catheterised 14 days after transplant, in the femoral artery and vein, using a sterile technique. After 3 days recovery, mice were infused for 4 days with $0.9 \%$ saline or $50 \%$ glucose (both wt/vol.) at $100 \mu \mathrm{l} / \mathrm{h}$ (approximately $2 \mathrm{~g} \mathrm{~kg}^{-1} \mathrm{~h}^{-1}$ ). Mice with elevated blood glucose 14 days after transplant $(>11.1 \mathrm{mmol} / \mathrm{l} ; n=5)$ received saline; mice with blood glucose $<11.1 \mathrm{mmol} / 1$ received either saline $(n=6)$ or glucose $(n=8)$. Three grafts, all from donor 10, did not have blood glucose measured on day 14 after transplant; all three had hyperglycaemia during the infusion period $(14.2,24.2$ and $29.3 \mathrm{mmol} / \mathrm{l})$ and were put in the $>11 \mathrm{mmol} / \mathrm{l}$ blood glucose group. When several normoglycaemic grafted mice were available from one donor (donors 4, 5, 7 and 9 [Table 1]), one mouse received saline and the other(s) received glucose. Grafts from donors 1, 8 and 10, and one graft from donor 11, had blood glucose $>11 \mathrm{mmol} / \mathrm{l}$. Infusates contained $250 \mu \mathrm{g} / \mathrm{ml} \mathrm{BrdU}$, for continuous exposure of $25 \mu \mathrm{g} / \mathrm{h}$ over the 4 days. Morning (postprandial) arterial blood was sampled from the unhandled mice via catheter at $0,24,48,72$ and $96 \mathrm{~h}$ of infusion. Following infusion, the mice were killed, and pancreases and engrafted kidneys fixed for histological analysis.

Biochemical analyses Blood glucose was measured using a portable glucometer (Precision QID; Abbot Laboratories,
Abbot Park, IL, USA) before and a glucometer (Ascencia Elite XL; Bayer, Tarrytown, NY, USA) after catheterisation. Plasma mouse and human insulin were measured by radioimmunoassay (Millipore/Linco, St Charles, MO, USA); cross-reactivity of the human assay with human proinsulin is $<0.2 \%$ and with rodent insulin $<0.1 \%$. Crossreactivity of the rodent insulin assay with human insulin is high; mouse insulin values were obtained by subtracting measured human insulin from rodent (total) insulin.

Histological analyses Engrafted kidneys were fixed in Bouin's solution (Sigma, St Louis, MO, USA) for $4 \mathrm{~h}$ at room temperature, dehydrated, embedded in paraffin and sectioned $(5 \mu \mathrm{m})$. For BrdU/insulin immunofluorescence, sections were rehydrated, incubated in $1 \mathrm{~mol} / \mathrm{l} \mathrm{HCl}$ for $30 \mathrm{~min}$ at $37^{\circ} \mathrm{C}$, blocked in PBS with $5 \%$ vol./vol. goat serum and $1 \%$ (wt/vol.) BSA, and exposed overnight to anti-BrdU (1:200; Abcam, Cambridge, MA, USA) and antiinsulin (1:50; Invitrogen, Carlsbad, CA, USA) antibodies at $4^{\circ} \mathrm{C}$, followed by exposure to fluorescent secondary antibodies (Alexa 488 and 594 conjugated, 1:200, and Hoechst, 1:1,000; all from Invitrogen). For macrophage marker F4/80-insulin-BrdU-DAPI co-staining, paraffin sections were rehydrated, digested with pepsin (Digest-All; Invitrogen), permeabilised in $0.1 \%$ vol./vol. Triton X-100 in PBS, blocked and stained exactly as above using primary antibodies for insulin (1:500; Invitrogen), F4/80 (1:100; Abcam) and BrdU (1:5; Amersham, Piscataway, NJ, USA), and an additional secondary antibody conjugated to $\mathrm{Cy} 5$ (1:200; Invitrogen). TUNEL staining was performed using a kit (Dead End kit; Promega, Madison, WI, USA) followed by immunofluorescence staining for insulin and Hoechst as above. 
Microscopy and image analysis For BrdU and TUNEL quantification, stained sections were imaged using an upright fluorescence microscope (Provis; Olympus, Center Valley, PA, USA) at $\times 400$, blinded and insulin-positive and TUNEL- or BrdU-positive beta cells manually counted. For BrdU, 3,034 \pm 246 beta cells were counted per graft; for TUNEL 2,618 \pm 317 beta cells were counted per graft. To verify BrdU and insulin colocalisation in the same cell and to determine whether insulin-positive BrdU-positive cells represented macrophages engulfing dying beta cells, confocal microscopy was performed (Fluoview 1000; Olympus) at $\times 400$.

Statistical analyses All data are presented as mean \pm SEM or as individual values. Statistical significance was calculated by Prism 4 (GraphPad Software, La Jolla, CA, USA), using Student's $t$ tests. One-way ANOVA was used when comparing multiple groups, with Tukey's Multiple Comparison Test. Two-way ANOVA was used when comparing blood glucose differences over time between infusion groups. Linear regressions were calculated by GraphPad Prism, with reported $p$ values signifying whether the slope of the regression line was significantly different from zero. For all analyses, $p<0.05$ was considered significant.

\section{Results}

Human islets transplanted into diabetic NOD-SCID mice reversed hyperglycaemia The experimental protocol is depicted in Fig. 1. The majority of grafts normalised blood glucose within 2 weeks of transplant (blood glucose $<11 \mathrm{mmol} / \mathrm{l}, n=14$ ) (Fig. 2a). Grafts that failed to normalise blood glucose (blood glucose $>11 \mathrm{mmol} / \mathrm{l}, n=8$ ) (Fig. 2a) were continued through the protocol to obtain data for human beta cells chronically exposed to higher blood glucose levels. Blood glucose values dipped 1 day after transplant, rebounded slightly and then slowly descended to stable levels by 2 weeks after transplant. With one exception, duplicate grafts were similarly effective in normalising blood glucose (Fig. 2b). Successful blood glucose normalisation was not significantly associated with donor age, BMI, sex, islet purity or islet viability (data not shown).

Human islet grafts were the sole source of circulating insulin in the transplanted mice Histological analysis of the endogenous mouse pancreas after death verified mouse beta cell ablation by streptozotocin without re-growth. Only rare, small, abnormal-appearing islets were observed, with few to no beta cells (Fig. 2c). Circulating mouse insulin was undetectable (Fig. 2d).

Human islet grafts were exposed to a wide range of blood glucose during the infusion period of BrdU exposure Blood glucose remained elevated in the $>11 \mathrm{mmol} / \mathrm{l}$ blood glucose group and remained low in normoglycaemic mice infused with saline (Fig. 3a). Note that samples were morning, postprandial samples. In general, blood glucose values during infusion were slightly lower than pre-infusion, presumably due to differences in sampling method (tail snip vs arterial catheter). Mice infused with glucose showed a significant increase in circulating blood glucose and plasma

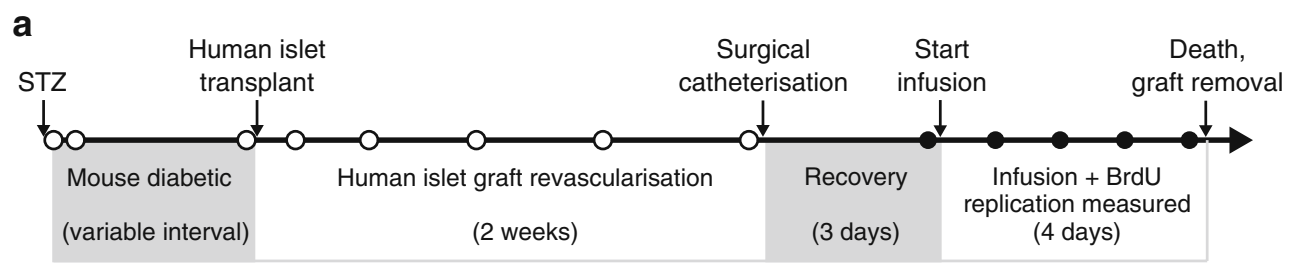

b Schematic of infusion groups:

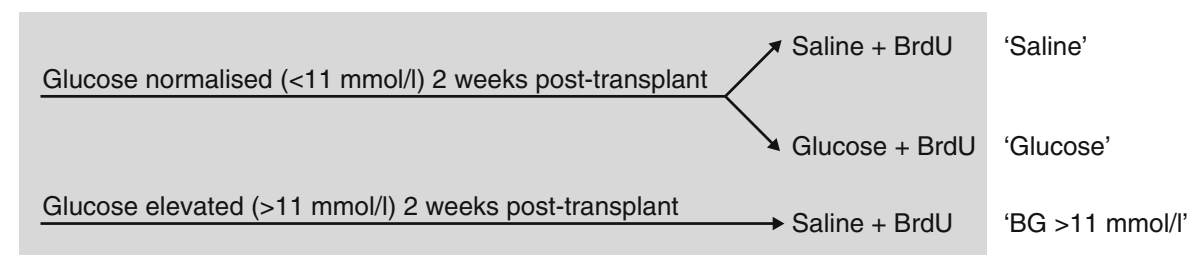

Fig. 1 Experimental design. a NOD-SCID mice were rendered diabetic using streptozotocin (STZ) and then transplanted with a therapeutic dose of human islets under the kidney capsule. After a 2 week graft revascularisation period, mice were catheterised in the femoral artery and vein, and intravenously infused with BrdU to label replicating beta cells over a 4 day period. Serial blood samples were taken for measurement of blood glucose after transplant (tail snip, white circles) and during the infusion BrdU exposure (arterial catheter sample, black circles). After the 4 day infusion mice were killed, and the graft was removed and processed for histological analysis. b Mice in which the human islet graft normalised blood glucose $(<11 \mathrm{mmol} / \mathrm{l})$ received either $0.9 \%$ saline or $50 \%$ glucose co-infused with $\mathrm{BrdU}$, to generate a range of blood glucose levels during the labelling period. Mice that remained diabetic after transplantation received infused saline during the BrdU exposure period 


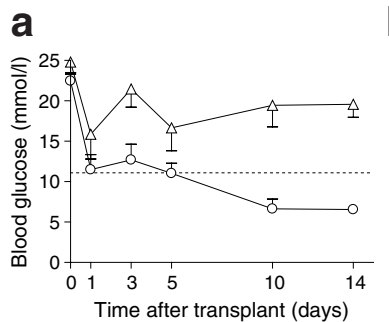

b
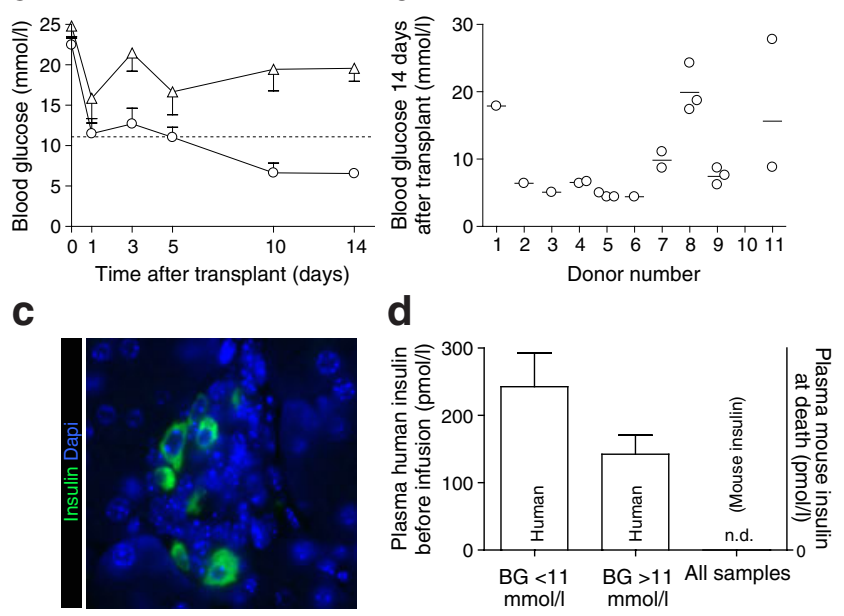

Fig. 2 Human islet grafts supported the metabolism of recipient mice. a Serial blood glucose measurements in transplanted mice demonstrated resolution of diabetes in the majority of mice (blood glucose $<11 \mathrm{mmol} / 1, n=14$, circles). A subset of mice had persistent hyperglycaemia (blood glucose $>11 \mathrm{mmol} / \mathrm{l}, n=8$, triangles). The dotted line denotes the blood glucose threshold of $11 \mathrm{mmol} / \mathrm{l}$. b Mice with grafts from the same donor showed similar transplant outcome, as demonstrated by blood glucose 14 days after transplant. Mice engrafted with islets from donor 10 had no blood glucose measurement at this time point; all these grafts had blood glucose $>11 \mathrm{mmol} / 1$ during the infusion period. c Histological examination of the endogenous mouse pancreas demonstrated ablation of mouse beta cells. Only rare, scattered insulin-positive cells (green) were found. d Circulating human insulin levels tended to be higher in mice with grafts that normalised blood glucose than in those in which the graft failed, although the difference did not achieve significance $(p=0.18)$. Circulating rodent insulin levels were undetectable (n.d., not detectable)

human insulin during the infusion period (Fig. 3a, b). The range of blood glucose and human insulin levels can be seen in Fig. 3c. Note that all replication analyses (see below) are based on cumulative BrdU exposure during this 4 day infusion period. Examination of circulating human insulin relative to blood glucose showed that most mice clustered in one region, with glucose at 3.0 to $8.0 \mathrm{mmol} / \mathrm{l}$ and insulin at 100 to $350 \mathrm{pmol} / 1$ (Fig. 3c). Mice that remained hyperglycaemic despite the human islet graft had relatively less circulating human insulin on average than mice infused with glucose (Fig. 3c, d).

Among grafts from the same donor, 4 days of higher blood glucose stimulated human beta cell proliferation BrdUpositive nuclei were easily visualised in non-beta cells in graft sections and were occasionally found in human beta cells. Confocal microscopy confirmed that BrdU-positive nuclei were associated with insulin-positive cytoplasm (Fig. 4a-d). To exclude the possibility that colocalisation of BrdU with insulin represented cells of monocyte lineage that had incorporated BrdU, travelled to the graft and then engulfed insulin-positive material, we co-labelled graft sections with BrdU, insulin and the macrophage marker $\mathrm{F} 4 / 80$. Control liver tissue demonstrated F4/80 staining as expected, without non-specific labelling (Fig. 4e, f). Macrophages were observed in graft sections, most frequently in the kidney tissue near the graft perimeter, and also occasionally within the graft tissue itself (Fig. 4g). Non-specific F4/80 staining was not observed in graft tissue (Fig. 4h). BrdUpositive insulin-positive cells did not co-localise with F4/80 staining (Fig. 4i-k).

Previous studies have shown that 4 day exposure of normal mouse pancreatic beta cells to mild hyperglycaemia induces beta cell replication [13]. To determine whether 4 days of hyperglycaemia stimulated engrafted human beta cell proliferation, we restricted analysis to donor pairs in which: (1) islets from one donor were transplanted into at least two mice; (2) blood glucose was normalised in all recipients; and (3) the resulting mice were infused with either saline or glucose to yield a range of blood glucose environments for a 4 day period. In these mice, beta cell

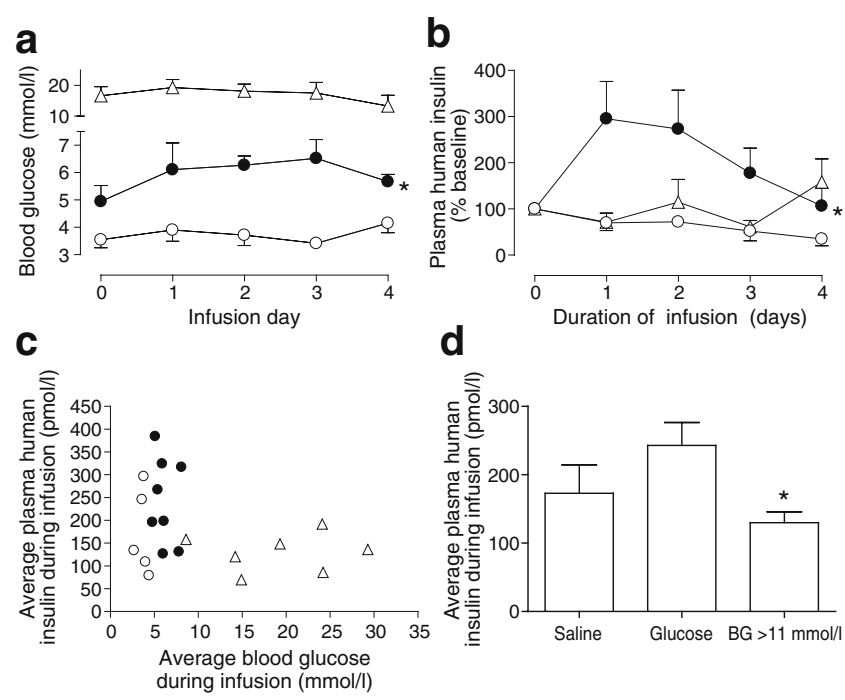

Fig. 3 Metabolic environment during the period of BrdU exposure. a Blood glucose remained elevated in the $>11 \mathrm{mmol} / 1$ blood glucose group (triangles) and low in the normoglycaemic saline group (white circles), but increased slightly in mice receiving glucose infusions (black circles). ${ }^{*} p=0.0009$ vs saline by two-way ANOVA (preinfusion sample at time zero excluded). b Plasma human insulin levels increased relative to baseline in the glucose-infused group (black circles); ${ }^{*} p=0.04$ vs saline (white circles) by two-way ANOVA (preinfusion sample at time zero excluded). White triangles, $>11 \mathrm{mmol} / 1$ blood glucose. c Average blood glucose and human insulin values for each mouse over the infusion period show that the majority of grafts maintained glucose and insulin within a defined region. Plasma insulin was not measured for one mouse in the $>11 \mathrm{mmol} / 1$ blood glucose group (triangles) and in one mouse in the saline group (white circles). Black circles, glucose infusion. d During BrdU exposure, grafts in the $>11 \mathrm{mmol} / \mathrm{l}$ blood glucose $(\mathrm{BG})$ group showed relatively lower circulating human insulin than grafts in mice infused with glucose. $* p<0.05$ for blood glucose $>11 \mathrm{mmol} / 1$ vs glucose infusion by oneway ANOVA 

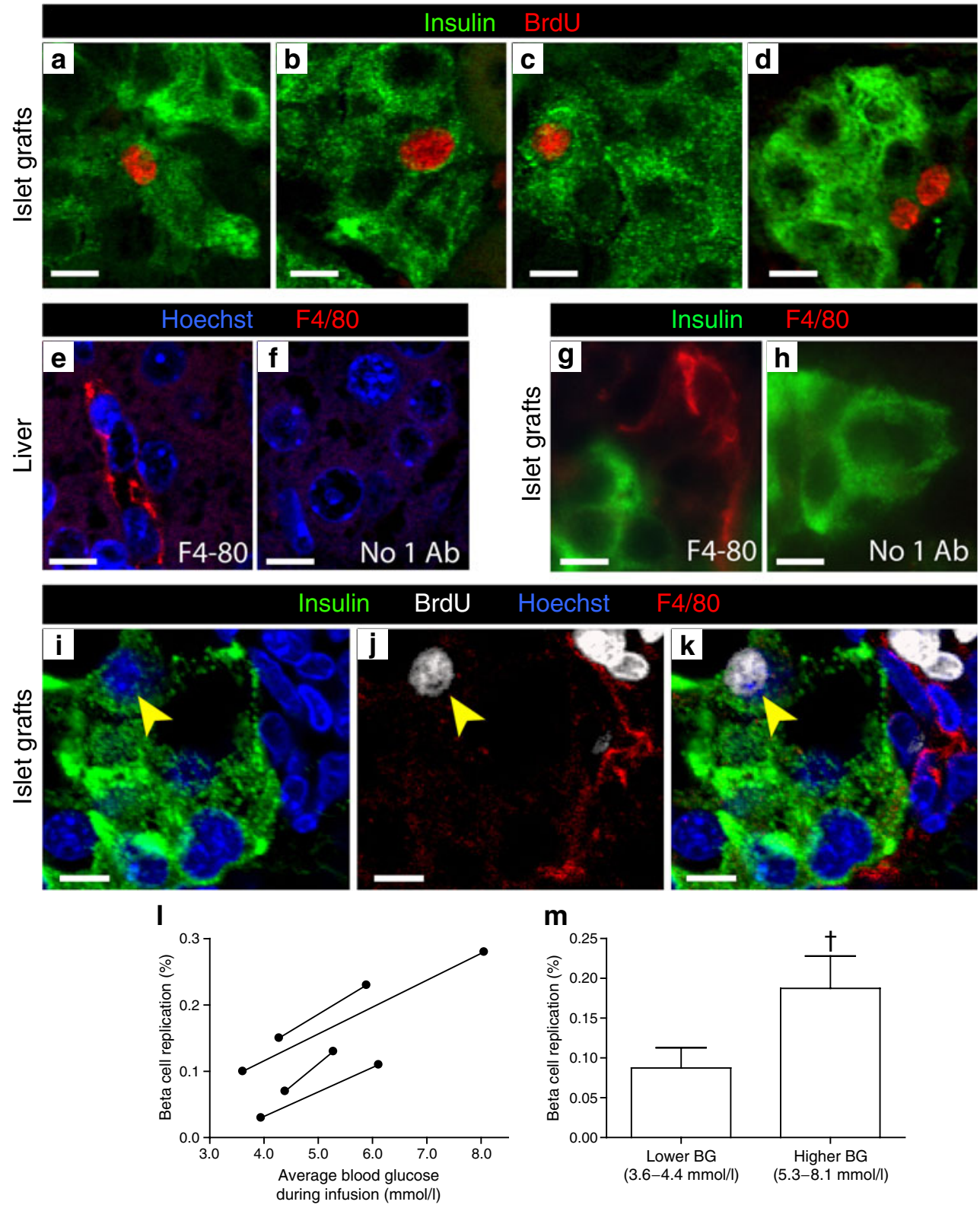

Hoechst F4/80
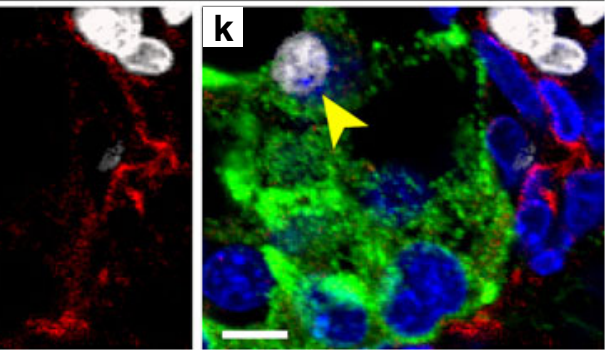

m

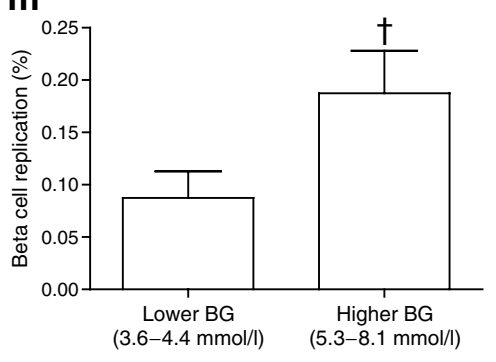

Fig. 4 In grafts from the same donors, higher blood glucose stimulated human beta cell replication. a-d Graft sections stained for insulin (green) and BrdU (red) allowed quantification of human beta cell replication. Images are representative examples of BrdU-positive beta cells, acquired by confocal microscopy. Note that the 4 day BrdU exposure resulted in labelling of daughter cells. e-k To exclude the possibility that BrdU-positive and insulin-positive cells were cells of monocyte lineage that had incorporated BrdU, subsequently entering the graft and engulfing insulin-positive material, macrophages were immunolabelled with F4/80 (red). e, f Control liver sections labelled with F4/80 and Hoechst (blue) demonstrated appropriate staining without non-specific signal. $\mathbf{g}, \mathbf{h}$ Graft sections stained for insulin (green) and F4/80 (red) also showed specific F4/80 label in and

replication among grafts from the same donor was higher in those grafts exposed to higher blood glucose (Fig. 41). The increase in replication was remarkably consistent among donors. The absolute rate of replication intrinsic to each around grafts, which was not present in the absence of the F4/80 antibody. i-k Graft sections stained for insulin (green), BrdU (white), Hoechst (blue) and F4/80 (red) were imaged by confocal microscopy. Note (yellow arrowheads) the BrdU-positive nucleus that belongs to an insulin-positive cell that is not F4/80-positive. Scale bars, $10 \mu \mathrm{m}$. I Analysis restricted to donors for which saline-infused and glucoseinfused mice were available showed a widely variable baseline replication rate among donors. However, human beta cell replication increased consistently across all donors with exposure to 4 days of higher blood glucose. $\mathbf{m}$ Despite the widely variable baseline replication rates, higher glucose significantly increased human beta cell replication $\left({ }^{\dagger} p=0.03\right.$ by paired $t$ test). For these four donors, $9,041 \pm 1,907$ beta cells were counted per donor

donor was variable, underscoring the difficult nature of human beta cell research. When the rates were averaged for these four donors, human beta cell replication was doubled in grafts exposed to higher glucose (Fig. $4 \mathrm{~m}$ ). 
Across the cohort, higher blood glucose increased human beta cell replication Analysing replication in the entire cohort of adult grafts showed a dose-dependent increase in human beta cell BrdU incorporation across a wide range of blood glucose (Fig. 5a). The correlation between blood glucose and replication was strongest for grafts exposed to blood glucose $<16.7 \mathrm{mmol} / \mathrm{l}$, but was still highly significant when all grafts were included. Circulating blood glucose correlated with increased beta cell replication even when the glucose group $(n=8)$ was analysed independently $(p=0.039$ for glucose mice; correlation not depicted on plot to aid readability) (Fig. 5a). Two grafts from a 7-year-old donor are shown as a positive control, but were not included in any statistical analyses. Note that the grafts from this juvenile donor also showed increased replication in the graft exposed
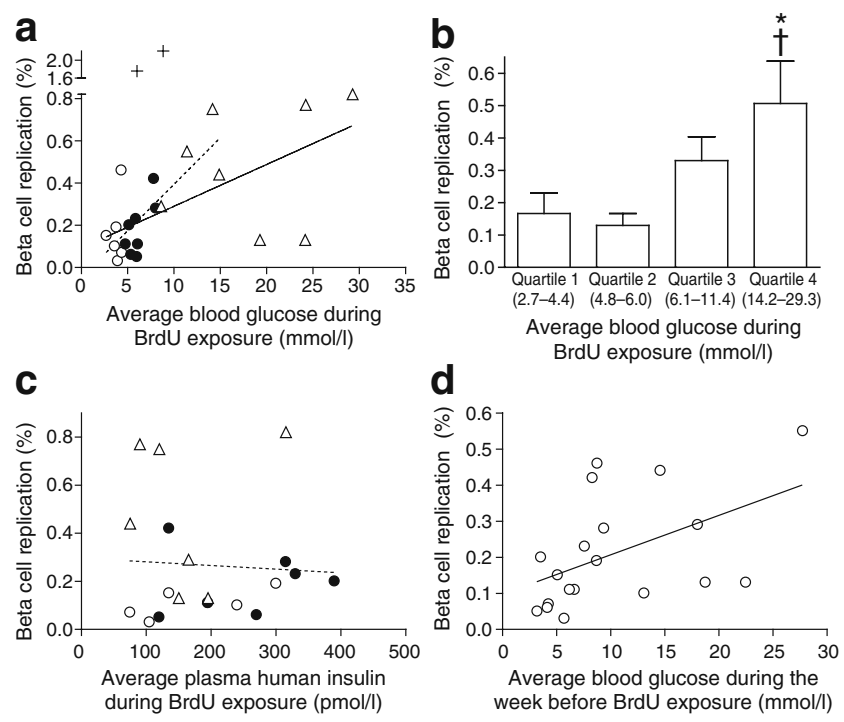

Fig. 5 Across the cohort of human islet grafts, hyperglycaemia increased human beta cell replication. a Average blood glucose during 4 day BrdU exposure significantly correlated with human beta cell replication. The correlation was strongest for animals that maintained blood glucose $<16.7 \mathrm{mmol} / 1$ (dashed line; $p=0.0001, r^{2}=0.60$ ), but was highly significant even when all animals were included (continuous line; $p=0.0019, r^{2}=0.39$ ). Grafts from a 7 -year-old donor $(+)$ were included as a positive control for replication, but were not included in analyses. b Bin analysis of adult human beta cell replication by blood glucose quartile found that replication increased for blood glucose values above $6.0 \mathrm{mmol} / \mathrm{l}$, reaching significance at the highest quartile. ${ }^{*} p<0.05$ vs quartile 1 and ${ }^{\dagger} p<0.05$ vs quartile 2 , calculated by ANOVA across all groups. $\mathbf{c}$ Graft beta cell replication showed no relationship with circulating plasma human insulin level; $p=\mathrm{NS}$. Plasma insulin was not measured for one mouse in the $>11 \mathrm{mmol} / 1$ blood glucose group and one mouse in the saline group; two grafts in the glucose infusion group had exactly the same plasma human insulin and replication rates $(198 \mathrm{pmol} / 1$ insulin, $0.11 \%$ replication), and thus are superimposed. d Graft beta cell replication correlated with blood glucose during the week prior to $\operatorname{BrdU}$ exposure $\left(p=0.03, r^{2}=0.24\right)$. Three grafts (donor 10) did not have blood glucose measured during the week prior to BrdU exposure. Key (a, c): white circles, saline; black circles, glucose infusion; triangles, blood glucose $>11 \mathrm{mmol} / 1$ to higher glucose (Fig. 5a). Grafts exposed to very high blood glucose $(>16.7 \mathrm{mmol} / \mathrm{l})$ showed more variability in proliferation; two grafts had high rates, but two others had low rates.

When the cohort was analysed by blood glucose quartile (Fig. 5b), human beta cell replication increased above blood glucose $6.0 \mathrm{mmol} / \mathrm{l}$, reaching significance for the highest glucose quartile relative to the two lowest quartiles.

We also explored whether human beta cell proliferation correlated with circulating plasma human insulin levels. Autocrine and/or paracrine insulin action is a putative mechanism by which glucose might stimulate beta cell mitogenesis [32]. In these grafts, human beta cell replication did not correlate with circulating plasma human insulin (Fig. 5c).

As we obtained blood glucose data from the period after transplant but before catheterisation, we sought to determine whether prolonged hyperglycaemia had an effect on transplanted human beta cell replication. When beta cell replication was compared with blood glucose during the week prior to catheterisation, (second week after transplant), a positive correlation was observed (Fig. 5d). This suggests that at least 2 weeks of hyperglycaemia in this range of blood glucose concentration did not prevent human beta cell proliferation.

Elevated glucose was not associated with human beta cell apoptosis Rare TUNEL-positive beta cells were found in human islet grafts; representative images are shown in Fig. 6a-c. In this cohort, high glucose was not associated with increased apoptosis at the end of the experiment (Fig. 6d). When grafts from the same donor were compared with each other, higher blood glucose was not associated with increased or decreased TUNEL-positive beta cells. The percentage of TUNEL-positive beta cells was not related to circulating human insulin, donor age or donor BMI (Fig. 6e and data not shown).

Adult human beta cell replication correlated with donor BMI but not age Intriguingly, graft human beta cell replication showed a trend towards a positive correlation with increasing donor BMI (Fig. 7a). When replication was analysed with respect to donor age, however, no age-related decline in replication was found in this cohort (Fig. 7b). Mice engrafted with islets from the oldest donor also had higher blood glucose levels, which perhaps masked an agerelated decline in human beta cell proliferation.

\section{Discussion}

We have found that glucose drives human beta cell proliferation in vivo in a transplant setting. Regardless of 
Fig. 6 Human beta cell apoptosis was not increased in grafts exposed to hyperglycaemia. a Sections from a mouse pancreas $6 \mathrm{~h}$ after intraperitoneal streptozotocin injection and $(\mathbf{b}, \mathbf{c})$ from human islet grafts, stained for insulin (red) and TUNEL (green) allowed quantification of apoptosis. Confocal images are representative examples of TUNEL staining of positive control. Scale bars $10 \mu \mathrm{m}$. d Quantification of TUNEL staining did not reveal a relationship between beta cell apoptosis and circulating blood glucose or (e) plasma human insulin, $p=\mathrm{NS}$ for both. Two mice (e) did not have plasma insulin measured, and three points are not visible due to grafts with identical TUNEL and insulin values
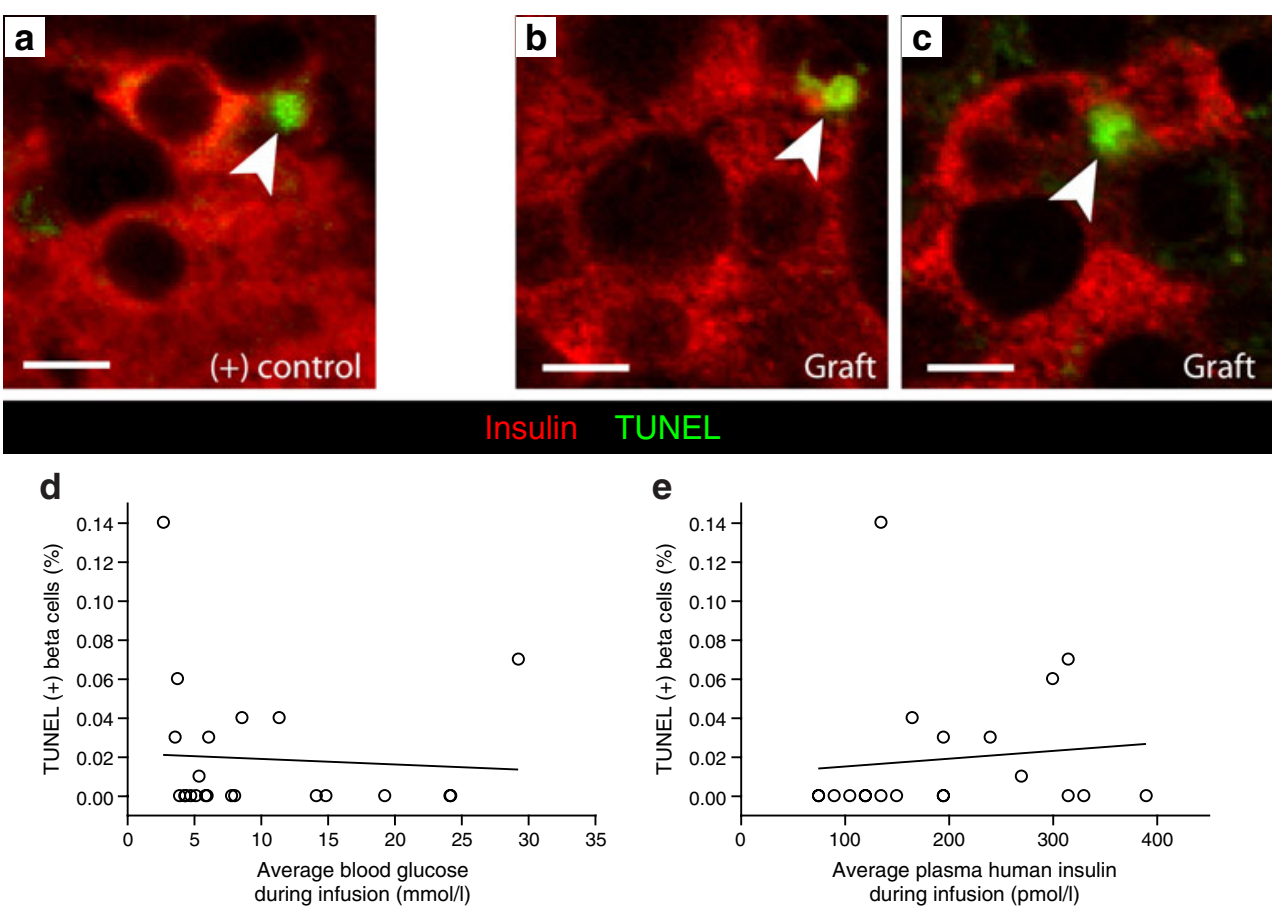

TUNEL

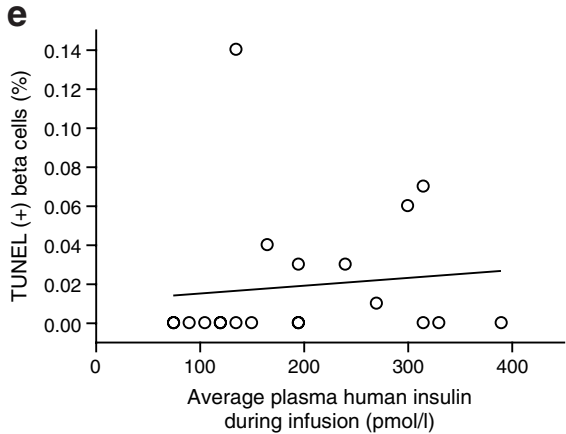

whether the data were analysed within individual donors exposed to 4 days of higher glucose or across the entire cohort of grafts, higher blood glucose led to increased human beta cell replication. Using this controlled model system, we were able to detect increases in beta cell replication associated with small changes in blood glucose, within or near the normal human postprandial range.

The most important finding of this study is the unequivocal demonstration that human beta cell replication increases, in vivo, in response to a moderate delta in blood glucose. To our knowledge, this represents the first direct evidence that human beta cell replication can be induced through a normal physiological stimulus in a setting where human islets are supporting metabolic requirements. Additional strengths include the novel technique of applying the
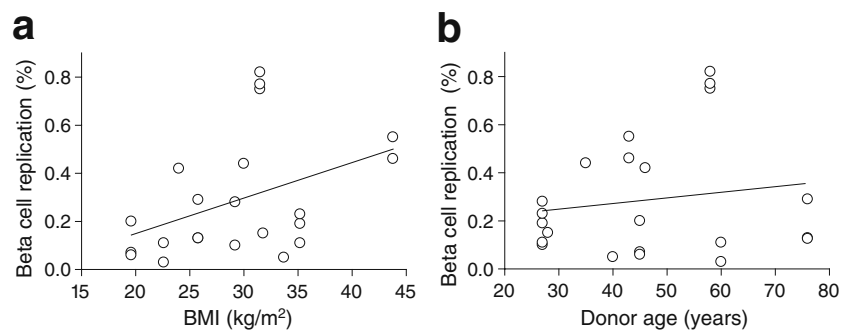

Fig. 7 Human beta cell replication was related to donor BMI but unrelated to donor age. a Replication showed a trend towards correlation with donor BMI in this cohort $\left(p=0.056, r^{2}=0.17\right)$. b No relationship between donor age and beta cell replication was observed across this cohort of human islet grafts. Two grafts from donor 8 (BMI $25.8 \mathrm{~kg} / \mathrm{m}^{2}$, age 76$)$ had identical replication rates $(0.13 \%)$ and the points are therefore superimposed $(\mathbf{a}, \mathbf{b})$ infusion system to transplanted human islets, and the potentially interesting observation that replication showed a trend towards correlation with donor BMI. Weaknesses stem from the intrinsic variability of cadaveric human islets and the generally low rate of replication in human beta cells. BrdU exposure was continuous for 4 days, so all replication events occurring during this time period, including daughter cells, were captured.

The optimal degree of hyperglycaemia to stimulate human beta cell replication is an important question. Our data suggest that to promote proliferation uniformly across all donors blood glucose elevation should not exceed $16.7 \mathrm{mmol} / \mathrm{l}$. This is in agreement with in vitro data that $33 \mathrm{mmol} / 1$ glucose reduced proliferation after 4 to 5 days in culture [23-25] and with in vivo data showing that transplanted human islets exposed to $24 \mathrm{mmol} / \mathrm{l}$ glucose for 14 days showed no increase in beta cell replication [26]. Our findings support the notion that glucose played a role in the proliferation increase seen in human islets transplanted into ob/ob mice (blood glucose $9 \mathrm{mmol} / \mathrm{l}$ ) [30]. These observations raise the interesting possibility that mild hyperglycaemia provides a permissive environment in which other mitogens can induce beta cell replication [33].

The optimal duration of hyperglycaemia needed to stimulate human beta cell proliferation is unknown. Prolonged hyperglycaemia has been shown to negatively impact rodent and human beta cell function and/or proliferation in a variety of studies [23-25, 34-38]. We found here that higher blood glucose during the period of BrdU exposure correlated with replication. Interestingly, blood glucose during the week before BrdU exposure also 
significantly correlated with replication. Blood glucose levels during BrdU exposure were strongly correlated with blood glucose levels in the week before BrdU exposure $\left(r^{2}=0.59, p=0.002\right)$. Therefore, prolonged mild glucose elevation may not inhibit beta cell replication in vivo. Since replication was not measured during any earlier period, we cannot exclude the possibility that proliferation rates were higher after a shorter exposure to hyperglycaemia. Interestingly, mouse beta cell replication only increased on the last day of a 4 day glucose infusion [13]. This lag between the onset of hyperglycaemia and the onset of proliferation might be exaggerated in human beta cells relative to mouse, given the low basal level of replication seen in human beta cells.

The model system used here is novel and will prove versatile for future studies. Transplanting human islets isolates them from their native donor environment, eliminating confounding issues related to peripheral insulin sensitivity and other tissue interactions with the beta cell. In this way, we were able to restrict human variability to factors intrinsic to the islets themselves. Transplantation allows culture beforehand, which provides an opportunity to pre-treat the islets with chemical modulators and/or for viral delivery of genes. Catheterisation has many benefits: unhandled blood sampling, sampling volumes that allow measurement of insulin and other factors, and co-administration of nutrients and medications. Also, continuous delivery of a constant amount of BrdU offers advantages over drinking water delivery in animal models of diabetes, in which hyperglycaemia-related polydipsia may alter BrdU exposure among study animals.

We found a trend towards correlation between beta cell replication and higher donor BMI. In rodents, genetic- and diet-induced obesity is a strong proliferative signal to beta cells [39]. In humans, autopsy studies have found that beta cell mass is increased in non-diabetic obese individuals; replication in human obesity is controversial [22, 40, 41]. The increased beta cell mass in obese non-diabetic people may be related to greater developmentally acquired beta cell mass, less beta cell death and/or increased beta cell replication. Our finding supports the concept that factors related to higher BMI, yet intrinsic to islets, might stimulate human beta cell replication. Recent work shows that islets from human donors with higher BMI have pro-proliferative changes at the transcriptional level compared with control islets [42].

Interestingly, in our cohort, donor age was not a determinant of beta cell proliferation among adult donors. However, beta cells from a 7-year-old donor did show markedly increased replication relative to all adult donors, consistent with published findings of high beta cell replication rates in youth [31]. Our cohort had only one donor over the age of 60 , so perhaps the spread of ages was not sufficient to detect an impact of age on proliferation. It may be worth noting that the two outlier points in Fig. 5a, with high glucose but very low replication rates, are both from the 76-year-old donor.

Beta cell death was not influenced by hyperglycaemia, donor age or donor BMI. Although there is strong evidence in the literature suggesting that chronic exposure to high glucose results in beta cell death [43] we did not detect this effect, even though several of the grafts were exposed to high blood glucose for longer than 2 weeks. The measured rates of TUNEL-positive beta cells were extremely low, in many cases undetectable, so potentially a correlation with hyperglycaemia might have been missed. Exposure to high glucose has been shown to increase expression of interleukin $1 \beta$ which may contribute to inflammation and beta cell death [44]. It is possible that beta cell death occurred at earlier time points.

Many unanswered questions remain. The discovery that glucose acts as a mitogen for transplanted human beta cells in vivo represents an important step towards identifying conditions in which human beta expansion can occur. In the future we plan to investigate which pathways are activated by glucose in human beta cells, which cell cycle molecules contribute to glucose-induced human beta cell replication and what are the optimal dose and duration of glucose exposure to induce human beta cell proliferation. Perhaps these data will provide the basis for a novel approach to human beta cell mass expansion, which may allow us to treat or even prevent, diabetes and its complications.

Acknowledgements We gratefully acknowledge access to human islet samples donated by individuals and provided by the Juvenile Diabetes Research Fund (JDRF), and the NIH/NCRR- and NIDDKsupported Islet Cell Resource Centers. This work was supported by JDRF innovative award 5-2008-189 (to L. C. Alonso and A. GarciaOcaña) and grants 1-2008-39 and 34-2008-630 (to A. F. Stewart). Support also came from NIH/NIDDK grants K08 DK076562 (to L. C. Alonso), R01 DK077096 (to A. Garcia-Ocaña) and R01 DK55023 (to A. F. Stewart), and NIH/NIDDK Beta Cell Biology Consortium grant U01 DK072473 (to A. F. Stewart) and NIH/NHLBI grant R01 HL063767 (to C. P. O'Donnell). We are especially grateful to R. Vasavada for her thoughtful reflection and comments, and to staff at investigator (L. C. Alonso, A. F. Stewart, A. Vasavada, A. GarciaOcana and C. P. O'Donnell) laboratories for their support and input.

Duality of interest The authors declare that there is no duality of interest associated with this manuscript.

\section{References}

1. Brissova M, Fowler MJ, Nicholson WE et al (2005) Assessment of human pancreatic islet architecture and composition by laser scanning confocal microscopy. J Histochem Cytochem 53:10871097

2. Cabrera O, Berman DM, Kenyon NS, Ricordi C, Berggren PO, Caicedo A (2006) The unique cytoarchitecture of human pancreatic islets has implications for islet cell function. Proc Natl Acad Sci USA 103:2334-2339 
3. Bosco D, Armanet M, Morel P et al (2010) Unique arrangement of alpha- and beta-cells in human islets of Langerhans. Diabetes 59:1202-1210

4. Parnaud G, Bosco D, Berney T et al (2008) Proliferation of sorted human and rat beta cells. Diabetologia 51:91-100

5. Shapiro AM, Lakey JR, Ryan EA et al (2000) Islet transplantation in seven patients with type 1 diabetes mellitus using a glucocorticoidfree immunosuppressive regimen. N Engl J Med 343:230238

6. Virtanen I, Banerjee M, Palgi J et al (2008) Blood vessels of human islets of Langerhans are surrounded by a double basement membrane. Diabetologia 51:1181-1191

7. De Vos A, Heimberg H, Quartier E et al (1995) Human and rat beta cells differ in glucose transporter but not in glucokinase gene expression. J Clin Invest 96:2489-2495

8. Eizirik DL, Pipeleers DG, Ling Z, Welsh N, Hellerstrom C, Andersson A (1994) Major species differences between humans and rodents in the susceptibility to pancreatic beta-cell injury. Proc Natl Acad Sci USA 91:9253-9256

9. De Vroede MA, In't Veld PA, Pipeleers DG (1990) Deoxyribonucleic acid synthesis in cultured adult rat pancreatic B cells. Endocrinology 127:1510-1516

10. Kaung HC (1983) Effect of glucose on beta cell proliferation and population size in organ culture of foetal and neonatal rat pancreases. J Embryol Exp Morphol 75:303-312

11. Swenne I (1982) The role of glucose in the in vitro regulation of cell cycle kinetics and proliferation of fetal pancreatic B cells. Diabetes 31:754-760

12. Swenne I, Bone AJ, Howell SL, Hellerstrom C (1980) Effects of glucose and amino acids on the biosynthesis of DNA and insulin in fetal rat islets maintained in tissue culture. Diabetes 29:686-692

13. Alonso LC, Yokoe T, Zhang P et al (2007) Glucose infusion in mice: a new model to induce beta-cell replication. Diabetes 56:1792-1801

14. Bonner-Weir S, Deery D, Leahy JL, Weir GC (1989) Compensatory growth of pancreatic beta-cells in adult rats after short-term glucose infusion. Diabetes 38:49-53

15. Jetton TL, Everill B, Lausier J et al (2008) Enhanced beta-cell mass without increased proliferation following chronic mild glucose infusion. Am J Physiol Endocrinol Metab 294:E679-E687

16. Steil GM, Trivedi N, Jonas JC et al (2001) Adaptation of beta-cell mass to substrate oversupply: enhanced function with normal gene expression. Am J Physiol Endocrinol Metab 280:E788-E796

17. Topp BG, McArthur MD, Finegood DT (2004) Metabolic adaptations to chronic glucose infusion in rats. Diabetologia 47:1602-1610

18. Pechhold K, Koczwara K, Zhu X et al (2009) Blood glucose levels regulate pancreatic beta-cell proliferation during experimentally-induced and spontaneous autoimmune diabetes in mice. PLoS ONE 4:e4827

19. Butler AE, Galasso R, Meier JJ, Basu R, Rizza RA, Butler PC (2007) Modestly increased beta cell apoptosis but no increased beta cell replication in recent-onset type 1 diabetic patients who died of diabetic ketoacidosis. Diabetologia 50:2323-2331

20. Meier JJ, Lin JC, Butler AE, Galasso R, Martinez DS, Butler PC (2006) Direct evidence of attempted beta cell regeneration in an 89 -year-old patient with recent-onset type 1 diabetes. Diabetologia 49:1838-1344

21. Menge BA, Tannapfel A, Belyaev O et al (2008) Partial pancreatectomy in adult humans does not provoke beta-cell regeneration. Diabetes 57:142-149

22. Butler AE, Janson J, Bonner-Weir S, Ritzel R, Rizza RA, Butler PC (2003) Beta-cell deficit and increased beta-cell apoptosis in humans with type 2 diabetes. Diabetes 52:102-110

23. Maedler K, Oberholzer J, Bucher P, Spinas GA, Donath MY (2003) Monounsaturated fatty acids prevent the deleterious effects of palmitate and high glucose on human pancreatic beta-cell turnover and function. Diabetes 52:726-733

24. Maedler K, Schumann DM, Schulthess F et al (2006) Aging correlates with decreased beta-cell proliferative capacity and enhanced sensitivity to apoptosis: a potential role for Fas and pancreatic duodenal homeobox-1. Diabetes 55:2455-2462

25. Maedler K, Spinas GA, Lehmann R et al (2001) Glucose induces beta-cell apoptosis via upregulation of the Fas receptor in human islets. Diabetes 50:1683-1690

26. Tyrberg B, Eizirik DL, Hellerstrom C, Pipeleers DG, Andersson A (1996) Human pancreatic beta-cell deoxyribonucleic acidsynthesis in islet grafts decreases with increasing organ donor age but increases in response to glucose stimulation in vitro. Endocrinology 137:5694-5699

27. Liu H, Remedi MS, Pappan KL et al (2009) Glycogen synthase kinase-3 and mammalian target of rapamycin pathways contribute to DNA synthesis, cell cycle progression, and proliferation in human islets. Diabetes 58:663-672

28. Rao P, Roccisana J, Takane KK et al (2005) Gene transfer of constitutively active Akt markedly improves human islet transplant outcomes in diabetic severe combined immunodeficient mice. Diabetes 54:1664-1675

29. Fiaschi-Taesch N, Bigatel TA, Sicari B et al (2009) Survey of the human pancreatic beta-cell $\mathrm{G} 1 / \mathrm{S}$ proteome reveals a potential therapeutic role for cdk-6 and cyclin D1 in enhancing human beta-cell replication and function in vivo. Diabetes 58 : 882-893

30. Tyrberg B, Ustinov J, Otonkoski T, Andersson A (2001) Stimulated endocrine cell proliferation and differentiation in transplanted human pancreatic islets: effects of the ob gene and compensatory growth of the implantation organ. Diabetes 50:301307

31. Meier JJ, Butler AE, Saisho Y et al (2008) Beta-cell replication is the primary mechanism subserving the postnatal expansion of beta-cell mass in humans. Diabetes 57:1584-1594

32. Assmann A, Ueki K, Winnay JN, Kadowaki T, Kulkarni RN (2009) Glucose effects on beta-cell growth and survival require activation of insulin receptors and insulin receptor substrate 2 . Mol Cell Biol 29:3219-3228

33. Hugl SR, White MF, Rhodes CJ (1998) Insulin-like growth factor I (IGF-I)-stimulated pancreatic beta-cell growth is glucose-dependent. Synergistic activation of insulin receptor substrate-mediated signal transduction pathways by glucose and IGF-I in INS-1 cells. J Biol Chem 273:17771-17779

34. Biarnes M, Montolio M, Nacher V, Raurell M, Soler J, Montanya E (2002) Beta-cell death and mass in syngeneically transplanted islets exposed to short- and long-term hyperglycemia. Diabetes 51:66-72

35. Merino JF, Nacher V, Raurell M, Aranda O, Soler J, Montanya E (1997) Improved outcome of islet transplantation in insulin-treated diabetic mice: effects on beta-cell mass and function. Diabetologia 40:1004-1010

36. Nacher V, Merino JF, Raurell M, Soler J, Montanya E (1998) Normoglycemia restores beta-cell replicative response to glucose in transplanted islets exposed to chronic hyperglycemia. Diabetes 47:192-196

37. Leahy JL, Bonner-Weir S, Weir GC (1988) Minimal chronic hyperglycemia is a critical determinant of impaired insulin secretion after an incomplete pancreatectomy. J Clin Invest 81: $1407-1414$

38. Laybutt DR, Glandt M, Xu G et al (2003) Critical reduction in beta-cell mass results in two distinct outcomes over time. Adaptation with impaired glucose tolerance or decompensated diabetes. J Biol Chem 278:2997-3005

39. Sachdeva MM, Stoffers DA (2009) Minireview: meeting the demand for insulin: molecular mechanisms of adaptive 
postnatal beta-cell mass expansion. Mol Endocrinol 23:747758

40. Hanley SC, Austin E, Assouline-Thomas B et al (2010) $\beta$-Cell mass dynamics and islet cell plasticity in human type 2 diabetes. Endocrinology 151:1462-1472

41. Yoon KH, Ko SH, Cho JH et al (2003) Selective beta-cell loss and alpha-cell expansion in patients with type 2 diabetes mellitus in Korea. J Clin Endocrinol Metab 88:2300-2308
42. Davis DB, Lavine JA, Suhonen JI et al (2010) FoxM1 is upregulated by obesity and stimulates beta cell proliferation. Mol Endocrinol 24:1822-1834

43. Poitout V, Robertson RP (2008) Glucolipotoxicity: fuel excess and beta-cell dysfunction. Endocr Rev 29:351-366

44. Maedler K, Sergeev P, Ris F et al (2002) Glucose-induced beta cell production of IL-1beta contributes to glucotoxicity in human pancreatic islets. J Clin Invest 110:851-860 